\title{
Detection and identification of Toxocara canis in infected dogs using PCR
}

\author{
H. ÖGE* , S. ÖGE, G. ÖZBAKIŞ-BECERIKLISOY
}

Ankara University, Faculty of Veterinary Medicine, Department of Parasitology, Ankara, Turkey, *E-mail: hoge@ankara.edu.tr

Article info

Received September 26, 2018

Accepted December 18, 2018

\section{Summary}

Faecal samples were collected from 224 dogs (47 villages) in Ankara. Toxocara spp. eggs were diagnosed in faeces using centrifugal flotation and sedimentation methods. A total of 21 dogs $(9.38 \%)$ were positive for Toxocara spp. eggs. In this study, we used the PCR technique that, in combination with DNA sequencing, allows the detection and identification of T.canis eggs in faeces of infected dogs. For this purpose, the ATPase subunit-6 gene (mtDNA) was selected as a target for the amplification $T$. canis. The primers were used to amplify $217 \mathrm{bp}$ region. Amongst 21 coproscopically detected Toxocara isolates from dogs, $5(23.8 \%)$ samples were PCR-positive for T. canis, and the remaining 16 samples were PCR-negative. Results indicate that PCR can detect Toxocara canis DNA in faeces of infected dogs, but efficacy was low when compare to sedimentation/flotation. PCR is additional test for diagnosing of this infection. But, the difficulties of identification based on PCR in faecal examinations need to be investigated further.

Keywords: Toxocara canis; dog; faecal examination; ATPase subunit-6

\section{Introduction}

Toxocariasis is a zoonosis with worldwide distribution caused by Toxocara species of dogs and cats. VLM in humans occurs primarily because of the ingestion of infective eggs (Macpherson, 2013; Strube et al., 2013). The ways of transmission to humans are as follows; soil and sandpits contamination in children, geophagia (Overgaauw \& Nederland, 1997; Macpherson, 2005; Bowman, 2009), ingestion of eggs contain infective larvae from dog's coat (Amaral et al., 2010; Macpherson, 2013; Öge et al., 2014), consumption of unwashed raw vegetables or fruits (Kozan et al., 2005; Lee et al., 2010), consumption of raw or undercooked meat containing arrested infective larvae in paratenic host (Lee et al., 2010; Macpherson, 2013; Strube et al., 2013), low socio-economic level and failure to regularly pick up and dispose of faeces (Overgaauw \& Nederland, 1997; Robertson \& Thompson, 2002).
In different countries, the prevalence of $T$. canis ranged between $4.4 \%$ and $33.8 \%$ in dogs (Habluetzel et al., 2003; Sager et al., 2006; Sowemimo, 2007; Claerebout et al., 2009; Soriano et al., 2010). The prevalence of $T$. canis varied from $4.2 \%$ to $47.8 \%$ in Turkey (Yıldırım et al., 2007; Kozan et al., 2007; Ünlü \& Eren, 2010; Çiçek \& Yılmaz, 2012). In dogs, routine diagnosis relies mainly on detection of eggs of the parasite in faeces. However, $T$. canis and $T$. cati are not to be clearly distinguishable by microscopy and serological diagnostic methods. The accurate identification of these species and differentiation from each other have an important role for investigating their life-cycles, epidemiology and specific diagnosis of toxocariasis.

The seroprevalence of human toxocariasis varies from $2.4 \%$ to $92.8 \%$ (Rubinsky-Elefant et al., 2010). In Turkey, the prevalence was found to be $7.6-26.42 \%$ in recent years (Kustimur et al., 2007; Karadam et al., 2008; Akdemir, 2010; Çiçek \& Yılmaz, 2012).

\footnotetext{
* - corresponding author
} 
PCR is used for rapid and specific diagnosis, because of their ability to specifically amplify DNA from nematode eggs and thinly sections of larvae or adult stages (Gasser, 2013; Smith et al., 2009). Primer design is the key step in PCR for the identification of parasites. ITS-1 and ITS-2 of nuclear rDNA sequences have been demonstrated to provide reliable genetic markers for the identification and differentiation of species of Toxocara and related nematodes (Jacobs et al,. 1997; Zhu et al., 1998; Li et al., 2007). In addition to nuclear ITS-1 and ITS-2 rDNA sequences, recent studies have shown that mtDNA useful alternative genetic markers for investigating of parasitic nematodes (Gasser, 2013). Various mitochondrial DNA regions have been employed for studying the population genetics of parasitic nematodes (Li et al., 2008; Wickramasinghe et al., 2009; Gasser, 2013). However, there is still limited information on the mt genomes of socioeconomically important Toxocara parasites. Therefore, there is need a suitable DNA target region (genetic marker) for the accurate identification of $T$. canis by PCR technique.

In addition to conventional methods, this coprological study was undertaken to detection and identification of Toxocara canis in infected dogs using PCR in the region of Ankara.

\section{Materials and Methods}

\section{Sample collection and faecal analysis}

Faecal samples taken from 224 dogs in 47 villages were investigated for Toxocara eggs. Age and sex of the dog were determined. Faecal samples were collected from dogs either within the area accessed by free or tethered dogs. For safety reasons, samples were frozen at $-80^{\circ} \mathrm{C}$ for 10 days before examination. Faecal samples were examined by sedimentation-formalin-ethyl acetate and centrifugal flotation with $\mathrm{ZnSO}_{4}$-solution (Truant et al., 1981). Eggs from all the Toxocara positive samples detected by flotation/sedimentation were examined by one step PCR to determine the $T$. canis. To concentrate eggs, faecal samples were prepared with improved flotation method (Szell et al., 2014). When Toxocara-type eggs were detected microscopically, $1 \mathrm{ml}$ of the upper part of the flotation from the centrifuge tube was transferred to the $15 \mathrm{ml}$ falcon tube. This step was repeated 4 times. The tube was filled with water and centrifuged at $2000 \mathrm{x} \mathrm{g} 10 \mathrm{~min}$. The supernatant was discarded, the sediment resuspended in $1 \mathrm{ml}$ water, transferred to a $2 \mathrm{ml}$ micro tube and these sediment was used for DNA purification.

\section{DNA isolation and PCR}

For the PCR, Toxocara egg DNA was extracted from faeces by QIAmp DNA Stool Mini kit (Qiagen), according to the manufacturer's instructions with the following modifications: The samples (sediment above defined) were subjected to $95^{\circ} \mathrm{C}, 30 \mathrm{~min}$ in Buffer $\mathrm{ASL}$, and proteinase $\mathrm{K}$ digestion was performed $70^{\circ} \mathrm{C}, 30 \mathrm{~min}$. Final dilution of DNA were made in $80 \mu \mathrm{l}$ of elution buffer and stored at $-20^{\circ} \mathrm{C}$ until using. The concentration of DNA in each sample was measured by a spectrophotometer (Thermoscientific Nanodrop-ND 2000) for qualitative and quantitative analyses. The isolates of eggs and adult of $T$. canis prepared in Özbakış' work (2015) were used for positive control sample. Also, distilled water was used as a negative-control.

A forward (T.canis ATP-F1: GTTTGTTGTTTTGGGGGCTA) and reverse (T.canis ATP-R1: CCAAAGGACGAGAAACCTCA) primers were used to amplify a $217 \mathrm{bp}$ region of the ATP synthase subunit 6 gene of $T$. canis (Özbakış, 2015). PCR was carried out in a $30 \mu \mathrm{l}$ total volume mix containing 10xTaq buffer (1.25 Ml including $\left.\left(\mathrm{NH}_{4}\right)_{2} \mathrm{SO}_{4}\right), 25 \mathrm{mmol} / \mathrm{L}$ of $\mathrm{MgCl}_{2}, 10 \mathrm{mM}$ of dNTP mix, $5 \mathrm{U} / \mu \mathrm{l} \mathrm{Taq}$ DNA polymerase (Fermentas, Waltham, MA, USA), water (18Mo$\mathrm{hm}-\mathrm{cm}$, AppliChem, Darmstadt, Germany), $10 \mathrm{pmol} / \mu \mathrm{l}$ primers and $10 \mu \mathrm{l}$ of template DNA. The reaction conditions were: $5 \mathrm{~min}$ at $94{ }^{\circ} \mathrm{C}$, followed by 34 cycles of $30 \mathrm{~s}$ denaturation at $94{ }^{\circ} \mathrm{C}, 1$ min annealing at $50^{\circ} \mathrm{C}, 1$ min extension at $72{ }^{\circ} \mathrm{C}$ and 10 min final extension at $72^{\circ} \mathrm{C}$, using a thermal cycler (PX2 Thermo, USA). Amplicons were detected on a 3\% agarose TAE gel with ethidium bromide-stained. It was visualized under the UV light with gel imaging system (NDR Bio-Imaging systems Mini Bis Pro).

\section{Sequencing analysis}

Toxocara egg products in 3 of PCR positive dogs were subjected to DNA sequencing. Subsequently, amplicons were clean-upped by High Pure PCR Clean-up microcit (Roche, Germany). Nucleotide sequence analysis was performed by Sentegen Biotechnolo-

Comparison of Toxocara egg prevalence in dogs' faeces/hair, soil, raw vegetables, and anti-Toxocara lgG positivity in human in Ankara, TURKEY

\begin{tabular}{|c|c|c|c|c|c|c|}
\hline \multirow[t]{2}{*}{ Province } & \multicolumn{2}{|c|}{ Dog } & \multirow[t]{2}{*}{ Soil (\%) } & \multirow[t]{2}{*}{ Vegetables (\%) } & \multirow[t]{2}{*}{ Human $(\%)$} & \multirow[t]{2}{*}{ References } \\
\hline & Faeces (\%) & Hair (\%) & & & & \\
\hline Ankara/TURKEY & $\begin{array}{c}9.38 \\
5\end{array}$ & $\begin{array}{l}14 \\
49\end{array}$ & $\begin{array}{c}30.6 \\
15.05\end{array}$ & 1.5 & 9.7 & $\begin{array}{l}\text { Present study } \\
\text { Öge et al., } 2014 \\
\text { Öge et al., } 2013 \\
\text { Oge \& Oge, } 2000 \\
\text { Avcioglu \& Burgu, } 2008 \\
\text { Kozan et al., } 2005 \\
\text { Kustimur et al., } 2007\end{array}$ \\
\hline
\end{tabular}


gy in Ankara and undertaken by BLAST algorithms and databases from the National Centre for Biotechnology (http://www.ncbi.nlm. nih.gov).

Phylogenetic analysis was performed in the Mega software (version 6.0) (Tamura et al., 2013). The tree was constructed using neighbour-joining method (Saitou \& Nei, 1987) based on Kimura 2-parameter model (Kimura, 1980) in the software package program. Bootstrap resampling was calculated from 1000 pseudo replicates with random seeds (Felsenstein, 1985).

\section{Ethical Approval and/or Informed Consent}

For this study formal consent is not required.

\section{Results and Discussion}

Toxocara eggs were detected in 21 of 224 dogs (9.38 \%). Toxocara canis was identified in 5 (23.8 \%) of the 21 Toxocara egg-positive samples by PCR (Fig. 1). But, efficacy of PCR was low when compare to sedimentation/flotation. The conventional parasitological examination is routinely used for diagnosis of toxocariasis in field. PCR has used for identification and differentiation of Toxocara species. The difference between $T$. canis and T. cati in ITS-1 and/ or ITS-2 of nuclear ribosomal DNA (rDNA) have been demonstrated by various authors (Jacobs et al., 1997; Zhu et al., 1998; Li et al., 2007; Borecka et al., 2008; Wickramasinghe et al., 2009; Fahrion et al., 2011). Recent studies have shown that sequences derived from the mtDNA genes provide alternative genetic marker for investigating genetic structures, systematics and phylogeny of parasitic nematodes (Wickramasinghe et al., 2009; Gasser, 2013). Mitochondrial DNA (mtDNA) markers can be used for investigating the taxonomy and genetics of Toxocara species. Conserved primers can be rationally and selectively designed in mitochondrial genome. Wickramasinghe et al. (2009) reported that the mitochondrial ATPase 6 genes were well conserved in Toxocara species and can be used for discrimination of species and for molecular phylogenetic. The important finding in this study was that only 5 out of 21 microscopically positive samples were PCR-positive T.canis. The other 16 dogs that were PCR negative were microscopically positive for Toxocara eggs. PCR efficacy depends on the number of eggs in faeces. PCR may not be able to detect DNA of ascarids as a result of low DNA concentration. We detected that the number of eggs in these faecal samples (epg) was very low in dogs (< 50). Toxocara species have the host specificity, i.e. T. cati for felids and T. canis for canids. But, Roth \& Schneider (1971) reported the findings of $T$. canis adults in the intestines of dissected cats. Some studies have suggested that coprophagy in dogs may be responsible for finding eggs of dog-typical (Sager et al., 2006) as well as dog-atypical (Fahrion et al., 2011). Dogs may consume their own faeces, faeces of other dogs and/or faeces of other species (Nijsse et al., 2014). Looking at the PCR results, in some dogs might have $T$. cati parasites instead of $T$. canis. But, this situation generally can not be explanation for the low PCR efficacy. That's why the result of faecal examination must be interpreted with carefully. The development of molecular diagnostic tests for identifying $T$. canis is important. Mainly $T$. cati resemble $T$. canis very closely in routine microscopic diagnosis and this may be lead to miss-identification. Toxocara cati might play a role in human toxocariasis than estimated rate, as there is no difference in the zoonotic potential of $T$. canis and T. cati (Oge et al., 2014).

The phylogenetic tree based on ATPase subunit- 6 gene sequences was able to distinguish between ascarid nematode samples and was used a Haemonchus contortus for an out group (Fig. 2). 244-407 bp were used in reference to FJ418787 accession number of $T$. canis gene data compared to phylogenetic tree. When the sequences data were compared with obtained T. canis sequences from GenBank database (Access. no: KJ777173, KJ777174, FJ418787, EU730761, JN593098) on ATPase subunit 6 gene between $98.2 \%$ and $99.4 \%$ homology exhibited. The identity between our T.canis samples and the reference T.canis samples was
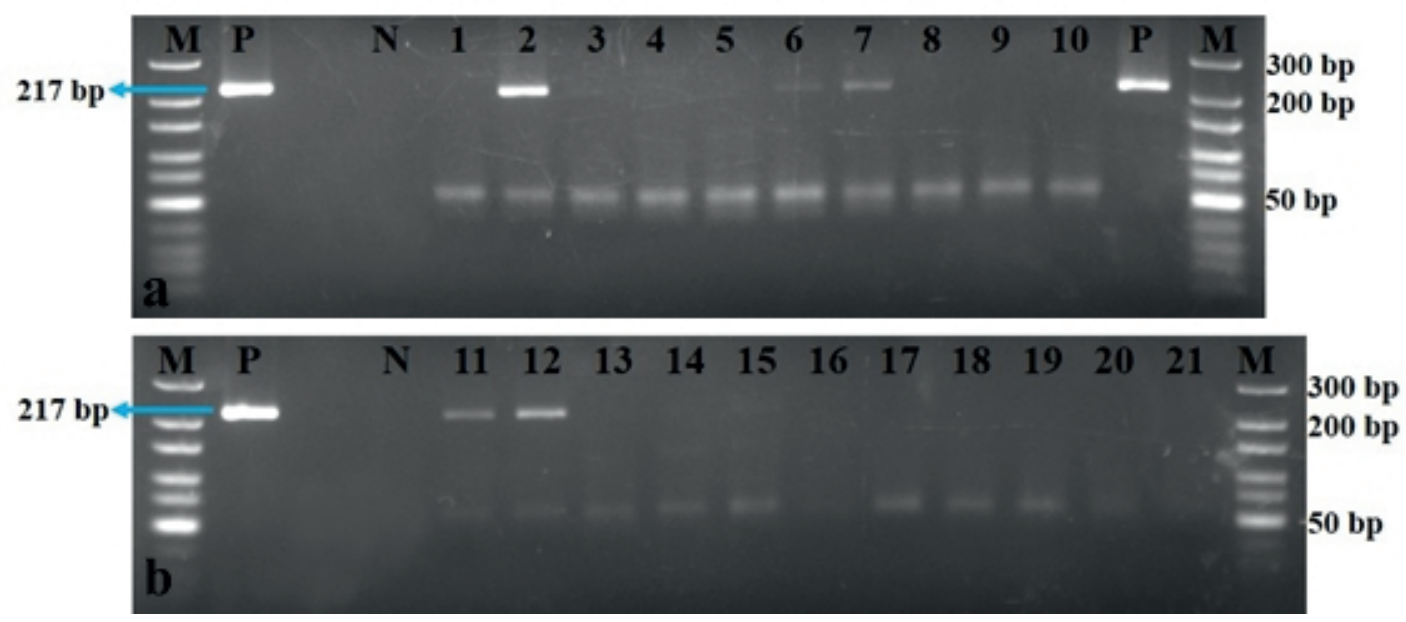

Fig. 1. Analysis of PCR products amplified of $T$. canis from faecal samples by agarose gel electrophoresis. M: Marker, PK: Positive control, NK: no DNA control, 1 - 21: Dog isolates 


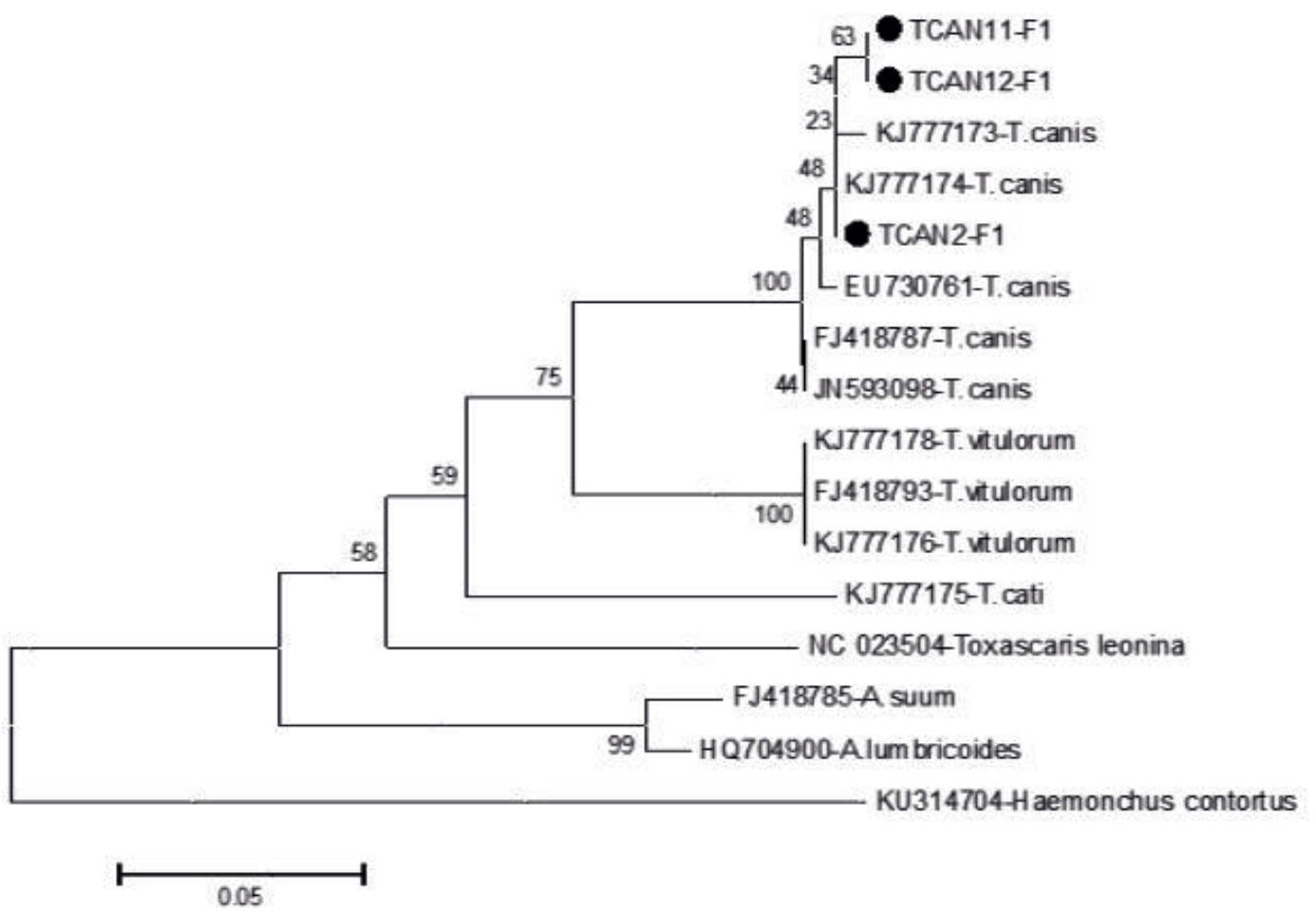

Fig. 2. The evolutionary history was inferred using the Neighbor-Joining method. The optimal tree with the sum of branch length= 0.66427549 is shown. The percentage of replicate trees in which the associated taxa clustered together in the bootstrap test (1000 replicates) are shown next to the branches. The tree is drawn to scale, with branch lengths in the same units as those of the evolutionary distances used to infer the phylogenetic tree. The evolutionary distances are in the units of the number of base substitutions per site.

low $(98.2 \%)$ considering it was such a small fragment (164 bp). tions with Toxocara spp. in dogs. The difficulties of identification Nucleotide sequence identities with each other of our samples (11, based on PCR in faecal examinations need to be investigated 12 and 2 number dog isolates) were found $100 \%, 100 \%$ and further.

$94.4 \%$, respectively.

Based on faecal analysis, Toxocara spp. eggs were found in the faeces of $9.38 \%$ of investigated dogs. The low prevalence of Toxocara infection in dogs in these villages could be attributed to the fact that the majority of dogs which were older than 2 years when looked at the raw data. Toxocara egg has been found in both young (5/43-11.62 \%) and adult (16/181-8.83 \%) animals. Adult dogs may still pose a risk to human health as they are susceptible to Toxocara infection.

The potential role of Toxocara parasites in human toxocariasis should not be ignored or underestimated. The presence of Toxocara spp. eggs was found in the soil, raw vegetables and dogs' faeces and hair in Ankara (Table 1). These situations are significant as the eggs have the potential to develop to infective larval stage and responsible for most VLM cases in humans. In the current study, the prevalence of Toxocara eggs in faeces is not high when compared with similar studies is not high when compared with similar studies (Öncel, 2004; Orhun \& Ayaz, 2006; Kozan et al., 2007; Ünlü \& Eren, 2007; Balkaya \& Avcıoğlu, 2011) but may be important.

The findings and considerations presented here indicate that we may have an imprecise image of true prevalence of patent infec-

\section{Conflict of Interest}

This research did not receive any specific grant from funding agencies in the public, commercial, or not-for-profit sectors.

\section{References}

AKDEMIR, C. (2010): Visceral larva migrans among children in Kütahya (Turkey) and an evaluation of playgrounds for $T$. canis eggs. Turk. J. Pediatr., 52(2): 158 - 162.

Amaral, H.L.C., Rassier, G.L., Pepe, M.S., Gallina, T., Villela, M.M., Nobre, M.O., ScainI, C.J., Berne, M.E.A. (2010): Presence of Toxocara canis eggs on the hair of dogs: A risk factor for Visceral Larva Migrans. Vet. Parasitol., 174(1-2): 115 - 118. DOI: 10.1016/j. vetpar.2010.07. 016

Avcioglu, H., BuRgu, A. (2008): Seasonal prevalence of Toxocara ova in soil samples from public parks in Ankara, Turkey. Vector Borne Zoonotic Dis., 8(3): 345 - 350. DOI: 10.1089/vbz. 2007.0212 BALKAYA, İ., Avcıŏ̌LU, H. (2011): Gastro-intestinal helminths detected by coprological examination in stray dogs in the Erzurum province-Turkey. Kafkas Univ. Vet. Fak. Derg., 17(Suppl A): S43 - S46. 
Borecka, A., Gawor, J., NiedWorok, M., SordyL, B. (2008): Detection of Toxocara canis larvae by PCR in the liver of experimentally infected Mongolian gerbils (Meriones unguiculatus). Helminthologia 45(3): 147 - 149. DOI: 10.2478/s11687-008-0029-9

Bowman, D.D. (2009): Georgis' Parasitology for Veterinarians. $9^{\text {th }}$ Edition, St Louis-Missouri, USA, Saunders Elsevier

Claerebout, E., Casaert, S., Dalemans, A.C., De Wilde, N., Levecke, B., Vercruysse, J., GeURden, T. (2009): Giardia and other intestinal parasites in different dog populations in Northern Belgium. Vet. Parasitol., 161(1-2): 41 - 46. DOI: 10.1016/j.vetpar.2008.11.024

ÇII̧EK, M., YILMAZ, H. (2012): Prevalence of toxocariasis in human and dogs in Van province. Kafkas Univ. Vet. Fak. Derg., 18(4): 531 - 536. DOI: 10.9775/kvfd.2011.5211

Fahrion, A.S., Schnyder, M., Wichert, B., Deplazes, P. (2011): ToXocara eggs shed by dogs and cats and their molecular and morphometric species-specific identification: Is the finding of $T$. cati eggs shed by dogs of epidemiological relevance? Vet. Parasitol., 177(1-2): 186 - 189. DOI: 10.1016/j.vetpar.2010.11.028

Felsenstein, J. (1985): Confidence limits on phylogenies: An approach using the bootstrap. Evolution, 39: 783 - 791. DOI: 10.1111/j.1558-5646.1985.tb00420.x

GASSER, R.B. (2013): A perfect time to harness advanced molecular technologies to explore the fundamental biology of Toxocara species. Vet. Parasitol., 193(4): 353 - 364. DOI: 10.1016/j.vetpar.2012.12.031

Habluetzel, A., Traldi, G., Ruggierl, S., Attlli, A.R., Scuppa, P., Marchetti, R., Menghini, G., Esposito, F. (2003): An estimation of Toxocara canis prevalence in dogs, environmental egg contamination and risk of human infection in the Marche region of Italy. Vet. Parasitol., 113(3 - 4): 243 - 252. DOI: 10.1016/S03044017(03)00082-7

JaCOBS, D.E., Zhu, X., Gasser, R.B., Chllton, N.B. (1997): PCRbased methods for identification of potentially zoonotic ascaridoid parasites of the dog, fox and cat. Acta Trop., 68(2): $191-200$. DOI: 10.1016/S0001-706X(97)00093-4

Karadam, S.Y., Ertug, S., ERtabaklar, H., Okyay, P. (2008): The comparison of $\mathrm{lg} G$ antibodies specific to Toxocara spp. among eosinophilic and non-eosinophilic groups. New Microbiol., 31: 113 - 116 KIMURA, M. (1980): A simple method for estimating evolutionary rate of base substitutions through comparative studies of nucleotide sequences. J. Mol. Evolution, 16: 111 - 120

Kozan, E., Gonenc, B., Sarimehmetoglu, O., Aycicek, H. (2005): Prevalence of helminth eggs on raw vegetables used for salads. Food Control 16(3): 239 - 242. DOI: 10.1016/j.foodcont.2004.02.005 Kozan, E., Kircal Sevimli, F., Birdane, F.M. (2007): The occurrence of gastrointestinal cestode and nematode infections in stray dogs in Afyonkarahisar and Eskisehir provinces. Türkiye Parazitol Derg., 31(3): $208-211$

Kustimur, S., Doğruman Al, F., Oguzulgen, K., Bakir, H., Maral, I., TÜRKTAS, H., TÜZÜN, H. (2007): Toxocara seroprevalence in adults with bronchial asthma. Trans. R. Soc. Trop. Med. Hyg., 101: $270-$ 274. DOI: 10.1016/j.trstmh.2006.08.013
Lee, A.C.Y., Schantz, P.M., Kazacos, K.R., Montgomery, S.P., BowMAN, D.D. (2010): Epidemiologic and zoonotic aspects of ascarid infections in dogs and cats. Trends Parasitol., 26(4): $155-161$. DOI: 10.1016/j.pt.2010.01.002

LI, M.W., LIN, R.Q., Chen, H.H., SANI, R.A., Song, H.Q., Zhu, X.Q. (2007): PCR tools for the verification of the specific identity of ascaridoid nematodes from dogs and cats. Mol. Cell. Probes., 21(56): 349 - 354. DOI: 10.1016/j.mcp.2007.04.004

LI, M.W., LIN, R.Q., Song, H.Q., Wu, X.Y., ZHU, X.Q. (2008): The complete mitochondrial genomes for three Toxocara species of human and animal health significance. BMC Genomics. 9: 224 233. DOI: $10.1186 / 1471-2164-9-224$

MACPHERSON, C.N.L. (2005): Human behaviour and the epidemiology of parasitic zoonoses. Int. J. Parasitol., 35(11-12): 1319 - 1331. DOI: 10.1016/j.jpara.2005.06. 004

MACPHERSON, C.N.L. (2013): The epidemiology and public health importance of toxocariasis: A zoonosis of global importance. Int. J. Parasitol., 43(12-13): 999 - 1008. DOI: 10.1016/j.jpara.2013.07.004 Nissse, R., Mughinl-Gras, L., Wagenaar, J.A., Ploeger, H.W. (2014): Coprophagy in dogs interferes in the diagnosis of parasitic infections by faecal examination. Vet. Parasitol., 204(3-4): $304-309$. DOI: 10.1016/j.vetpar.2014.05.019.

Oge, S., OGE, H. (2000): Prevalence of Toxocara spp. eggs in the soil of public parks in Ankara, Turkey. Dtsch. Tierarztl. Wochenschr., 107: $72-75$.

Orhun, R., Ayaz, E. (2006): Prevalence of helminths in dogs in the region of Van and their potential public health significance. Türkiye Parazitol. Derg., 30(2): 103 - 107.

Overgaauw, P.A.M., Nederland, V. (1997): Aspects of Toxocara epidemiology: toxocarosis in the human. Crit. Rev. Microbiol., 23(3): 215 - 231. DOI: 10.3109/10408419709115137

ÖGE, S., ÖGE, H., Gönenç, B., ÖZBakIş, G., Aștı, C. (2013): Presence of Toxocara eggs on the hair of dogs and cats. Ankara Üniv. Vet. Fak. Derg., 60: 171 - 176

ÖGE, H., ÖGE, S., ÖZBakIş, G., Gürcan, S. (2014): Comparison of Toxocara eggs in hair and faecal samples from owned dogs and cats collected in Ankara, Turkey. Vet. Parasitol., 206 (3-4): 227 231. DOI: 10.1016/j.vetpar.2014.10.005

ÖnCEL, T. (2004): Toxocariosis canis in domestic dogs in İstanbul, Turkey. Kafkas Üniv. Vet. Fak. Derg., 10(2): 151 - 153.

ÖZBAKIŞ, G. (2015): PCR detection of Visceral Larvae Migrans in mice experimentally infected with Toxocara canis. PhD Thesis, Ankara, Turkey: The Graduate School of Health Sciences of Ankara University

RoberTson, I.D., THompson, R.C. (2002): Enteric parasitic zoonoses of domesticated dogs and cats. Microbes Infect., 4(8): 867 - 873. DOI: 10.1016/S1286-4579(02)01607-6

ROTH, B., SCHNEIDER, C.C. (1971): Untersuchungen zur Abhangigkeiten des "weissen Blutbildes" bei Hauskatzen (Felis domestica) von Wurminfektionen des Darmes. [Relation of the white blood picture to intestinal helminth infestations in cats (Felis domestica)]. Berl. Munch. Tierarztl. Wochenschr., 84(22): 436 - 437 (In German) 
Rubinsky-Elefant, G., Hirata, C.E., Yamamoto, H.J., Ferreira, M.U. (2010): Human toxocariasis: diagnosis, worldwide seroprevalences and clinical expression of the systemic and ocular form. Ann. Trop. Med. Parasitol., 104(1): 3 - 23. DOI: 10.1179/136485910X1 2607012373957.

Sager, H., Moret, C.H.S., Grimm, F., Deplazes, P., Doherr, M.G., GotTSTEIN, B. (2006): Coprological study on intestinal helminths in Swiss dogs: temporal aspects of anthelminthic treatment. Parasitol. Res., 98(4): 333 - 338. DOI: https://doi.org/10.1007/s00436005-0093-8

SAltou, N., Nel, M. (1987): The neighbor-joining method: A new method for reconstructing phylogenetic trees. Mol. Biol. Evol., 4: 406 - 425. DOI: 10.1093/oxfordjournals.molbev.a040454

Smith, H., Holland, C., Taylor, M., Magnaval, J.F., Schantz, P., Maizels, R. (2009): How common is human toxocariasis? Towards standardizing our knowledge. Trends Parasitol., 25(4): 182 - 188. DOI: 10.1016/j.pt.2009.01.006

Soriano, S.V., Pierangeli, N.B., Roccia, I., Bergagna, H.F.J., Lazzarin, L.E., Celescinco, A., Salz, M.S., Kossman, A., Contreras, P.A., ArIAS, C., BASUALDO, J.A. (2010): A wide diversity of zoonotic intestinal parasites infects urban and rural dogs in Neuquen, Patagonia, Argentina. Vet. Parasitol., 167(1): 81 - 85. DOI: 10.1016/j. vetpar.2009.09.048

SoWEMIMO, O.A. (2007): Prevalence and intensity of Toxocara canis (Werner, 1782) in dogs and its potential public health significance in lle-lfe, Nigeria. J. Helminthol., 81(4): 433 - 438. DOI: 10.1017/ S0022149X07850267

Strube, C., Heuer, L., Janecek, E. (2013): Toxocara spp. infections in paratenic hosts. Vet. Parasitol., 193(4): 375 - 389. DOI: 10.1016/j.vetpar.2012.12.033
Szell, Z., Sreter-Lancz, Z., SReter, T. (2014): Evaluation of faecal flotation methods followed by species-specific PCR for detection of Echinococcus multilocularis in the definitive hosts. Acta Parasitol., 59(2): 331 - 336. DOI: 10.2478/s11686-014-0248-9

Tamura, K., Stecher, G., Peterson, D., Filipski, A., Kumar, S. (2013): MEGA6: Molecular Evolutionary Genetics Analysis version 6.0. Mol. Biol. Evol., 30: 2725 - 2729. DOI: 10.1093/molbev/mst197

Truant, A.A., Elliot, S.H., Kelly, M.T., Smith, J.H. (1981): Comparison of formalin-ethyl ether sedimentation, formalin-ethyl acetate sedimentation, and zinc sulphate flotation techniques for detection of intestinal parasites. J. Clin. Microbiol., 13(5): $882-884$

ÜnLL̈, H., EREN, H. (2007): Gastro-intestinal helminths detected by fecal examination in stray dogs in the Aydin province. Türkiye Parazitol. Derg., 31(1): $46-50$

YILdIRIM, A., İÇA, A., Düzlü, O., Yavuz, A., İNCI, A. (2007): The prevalence of gastrointestinal helminths in dogs by coprological examination in Kayseri province. Erciyes Üniv. Vet. Fak. Derg., 4(2): $65-71$

Wickramasinghe, S., Yatawara, L., Rajapakse, R.P.V.J., Agatsuma, T. (2009): Toxocara canis and Toxocara vitulorum: molecular characterization, discrimination, and phylogenetic analysis based on mitochondrial (ATP synthase subunit 6 and 12S) and nuclear ribosomal (ITS-2 and 28S) genes. Parasitol. Res., 104: 1425 - 1430. DOI: 10.1007/s00436-009-1345-9

Zhu, X.Q., Jacobs, D.E., Chllton, N.B., Sanl, R.A., Cheng, N.A.B.Y., GASSER, R.B. (1998): Molecular characterization of a Toxocara variant from cats in Kuala Lumpur, Malaysia. Parasitology 117: 155 $-164$ 